\title{
Research Note \\ The effects of heavy metals and pesticides on survival of miracidia stage of Fasciola hepatica
}

\author{
M. FALIS, I. KRUPICER, J. LEGÁTH, V. PITOŇÁK, M. ŠPALEK
}

University of veterinary medicine and pharmacy in Košice, Komenského 73, 041 81, E-mail:falis@uvm.sk

\begin{abstract}
Summary
The effect of heavy metals and pesticides on viability of miracidia stage of Fasciola hepatica was investigated. The experimental groups with chemicals were compared with the untreated control group. After 16 days of exposure, the groups contained $\mathrm{Cr}, \mathrm{Zn}, \mathrm{CdZn}$, exhibited decreased motility of miracidia inside the egg shells. In the groups which contain AGCr, GCdZn, CdCrZn and AGCdCrZn no effect on movement of emerged miracidia were observed. In the rest of the groups immobile or dead miracidia inside the egg shells have been identified. The possible protective effect of zinc on miracidia of Fasciola hepatica is discussed.
\end{abstract}

Keywords: azoxystrobin; glyphosate; miracidium; Fasciola hepatica; heavy metals

\section{Introduction}

Intensive agricultural production involves higher use of pesticides, in particular fungicides and herbicides, resulting in a higher burden on ecosystems. Growing environmental pollution calls for a focused interest in identifying the effects of interaction of various kinds of pollutants on living systems. The effect of heavy metals on sheep infected by gastro-intestinal nematodes has been studied previously (Krupicer, 1995; Krupicer et al., 1996). Investigation of interaction between pesticides and heavy metals, major contaminats of agricultural environment, on various growth stages of parasites contribute to better assessment of environmental status in rural areas. Negative effects on nontarget beneficial species as well as improvement of conditions for better viability of parasites and their growth stages, increasing the risk of the development of resistance to anthelmintics (Čerňanská et al., 2006; Várady et al., 2007; Dolinská et al., 2012) and will provoke a dramatic alteration of the structure and functioning of the agricultural ecosystem. The goal of this study was to investigate the ef- fects of azoxystrobin, glyphosate and selected heavy metals on viability of miracidium stage of Fasciola hepatica.

\section{Material and methods}

The experimental samples were divided into 25 exposed groups and control group was also included (Table 1). The following experimental solutions were used in study:

cadmium chloride dihydrate $\left(\mathrm{CdCl}_{2} .2 \mathrm{H}_{2} \mathrm{O}\right)$ with con-centration of $25 \mathrm{mg} . \mathrm{l}^{-1}$

- potassium dichromate $\left(\mathrm{K}_{2} \mathrm{Cr}_{2} \mathrm{O}_{7}\right)$ with concentration of $10 \mathrm{mg} . \mathrm{l}^{-1}$

- $\quad$ zinc sulfate heptahydrate $\left(\mathrm{ZnSO}_{4} \cdot 7 \mathrm{H}_{2} \mathrm{O}\right)$ with concentration of $100 \mathrm{mg} . \mathrm{l}^{-1}$

- glyphosate with concentration of $500 \mathrm{mg} . \mathrm{l}^{-1}$

- azoxystrobin with concentration of $0.2 \mathrm{mg} . \mathrm{l}^{-1}$ separately and in combinations.

All experimental solutions were diluted in distilled water. The sexually mature Fasciola hepatica were collected from livers of Cervus elaphus montanus. Adults of parasites were kept in the test tubes with Ringer's solution, until the eggs were released spontaneously. The eggs were kept in the dark at $4{ }^{\circ} \mathrm{C}$ until the examination. A $60 \mu \mathrm{l}$ of distilled water with considerable amount of eggs Fasciola hepatica were put in a depression slides. The same volume of solution with double concentration (Table 1) was added to a well, mixed properly and cover with coverslip. Before the experimental study the thermostat was subjected to disinfection (Kočišová, 2005). Slides were kept in the dark at $28^{\circ} \mathrm{C}\left(27.9-28.5^{\circ} \mathrm{C}\right)$ for 16 days. The relative humidity was maintained to $100 \%$. Each experimental set consisted of 5 depression slides with three hollows (15 replicates per group). Viability/movement of miracidia stage of Fasciola hepatica was observed by light stereomicroscope (DMS 5.0 FBGG) with high resolution digital video camera (OPTIKAM PRO 5, OPTIKA vision 3.6 software). 
Table 1. The experimental groups used in the study

\begin{tabular}{|c|c|c|c|c|c|}
\hline $\begin{array}{l}\text { Experimental } \\
\text { group }\end{array}$ & $\begin{array}{c}\text { Concentration } \\
\text { of } \mathrm{K}_{2} \mathrm{Cr}_{2} \mathrm{O}_{7} \\
(\mathrm{mg} / \mathrm{l})\end{array}$ & $\begin{array}{l}\text { Concentration } \\
\text { of } \mathrm{CdCl}_{2} .2 \mathrm{H}_{2} \mathrm{O} \\
(\mathrm{mg} / \mathrm{l})\end{array}$ & $\begin{array}{c}\text { Concentration } \\
\text { of } \mathrm{ZnSO}_{4} \cdot 7 \mathrm{H}_{2} \mathrm{O} \\
(\mathrm{mg} / \mathrm{l})\end{array}$ & $\begin{array}{c}\text { Concentration } \\
\text { of azoxystrobin } \\
(\mathrm{mg} / \mathrm{l})\end{array}$ & $\begin{array}{c}\text { Concentration } \\
\text { of glyphosate } \\
(\mathrm{mg} / \mathrm{l})\end{array}$ \\
\hline $\mathrm{C}$ & 0 & 0 & 0 & 0 & 0 \\
\hline A & 0 & 0 & 0 & 0.2 & 0 \\
\hline G & 0 & 0 & 0 & 0 & 500 \\
\hline $\mathrm{Cd}$ & 0 & 25 & 0 & 0 & 0 \\
\hline $\mathrm{Cr}$ & 10 & 0 & 0 & 0 & 0 \\
\hline $\mathrm{Zn}$ & 0 & 0 & 100 & 0 & 0 \\
\hline $\mathrm{AG}$ & 0 & 0 & 0 & 0.2 & 500 \\
\hline GCd & 0 & 25 & 0 & 0 & 500 \\
\hline $\mathrm{GCr}$ & 10 & 0 & 0 & 0 & 500 \\
\hline GZn & 0 & 0 & 100 & 0 & 500 \\
\hline $\mathrm{CdCr}$ & 10 & 25 & 0 & 0 & 0 \\
\hline $\mathrm{CdZn}$ & 0 & 25 & 100 & 0 & 0 \\
\hline $\mathrm{CrZn}$ & 10 & 0 & 100 & 0 & 0 \\
\hline AGCd & 0 & 25 & 0 & 0.2 & 500 \\
\hline $\mathrm{AGCr}$ & 10 & 0 & 0 & 0.2 & 500 \\
\hline AGZn & 0 & 0 & 100 & 0.2 & 500 \\
\hline $\mathrm{GCdCr}$ & 10 & 25 & 0 & 0 & 500 \\
\hline GCdZn & 0 & 25 & 100 & 0 & 500 \\
\hline GCrZn & 10 & 0 & 100 & 0 & 500 \\
\hline $\mathrm{CdCrZn}$ & 10 & 25 & 100 & 0 & 0 \\
\hline $\mathrm{AGCdCr}$ & 10 & 25 & 0 & 0.2 & 500 \\
\hline $\mathrm{AGCdZn}$ & 0 & 25 & 100 & 0.2 & 500 \\
\hline AGCrZn & 10 & 0 & 100 & 0.2 & 500 \\
\hline GCdCrZn & 10 & 25 & 100 & 0 & 500 \\
\hline AGCdCrZn & 10 & 25 & 100 & 0.2 & 500 \\
\hline
\end{tabular}

\section{Results and discussion}

The results of the motility/movement of the miracidia stage of Fasciola hepatica are shown in Table 2. In the control groups miracidia of Fasciola hepatica exhibited free movement of emerged miracidia in the microscopical preparation inside the egg shells. In the groups containing A, G, Cd, AG, GCd, GCd, GCr, GZn, CdCr, CrZn, AGCd, AGZn, GCdCr, GCrZn, AGCdCr, AGCdZn, AGCrZn, GCdCrZn immobile or dead miracidia inside the egg shells were identified. The groups containing $\mathrm{Cr}, \mathrm{Zn}, \mathrm{CdZn}$ exhibited reduction of motility/movements of non-emerged miracidia inside the egg shells. No differences in the movement between control groups and groups containing AGCr, GCdZn, CdCrZn, AGCdCrZn were observed.

No reduction of the movement of miracidia was observed in groups containing zinc separately and cadmium and zinc. Our observation would confirm well-known antagonistic effect between zinc compounds and cadmium (Koreneková, 2002; Kottferová, 2001; Dvořák, 2000). The viable miracidia have been also identified in groups containing chromium separately and groups with chromium (AGCr, CdCrZn, AGCdCrZn). Cadmium is a toxicologically relevant substance contaminating the environment. The primary site of the harmful effects of cadmium is cell membranes which lose their structural and functional properties (Kobroob, 2012). It inhibits the activity of nume- rous enzymes (Pathak, 2013; Kottferová, 2001). The biological antagonism of cadmium and zinc has been described (Liu, 1992).

Chromium is a biogenous element with effects on sugar and lipid metabolism. It's compounds cause protein coagulation and have corrosive effects (Kottferová, 2002). Zinc has significant affinity to nitrogen and sulphur containing ligands. In biological systems it can be found in relation with many organic substances such as proteins, aminoacids and nucleic acids. Zinc is an important biogenous element and an integral part of many metaloenzymes (Sousa, 2007).

Azoxystrobin, is one of the most used fungicide with a wide spectrum of effects to control major kinds of pathogeneous moulds, in particular of genus Ascomicetes, $\mathrm{Ba}$ sidiomycetes, Deuteromycetes and Oomycetes. It inhibits spore germination and mycelium growth (Clough, 1996). It ranks among the globally most widely-used fungicides. It is a derivative of naturally-occurring strobilurins. Their biochemical mode of action is inhibition of electron transport (U.S. EPA, 1997). Azoxystrobin is characterized as a substance hazardous for fish as well as other aquatic life. $\mathrm{EC}_{50}=259 \mathrm{ppb}$ makes it highly toxic for freshwater invertebrates such as the water flea. (US EPA) In an aquatic environment it is degraded through adsorption in sediments and subsequent microbial degradation. (Syngenta Group, 2005) The half-life of photolytic degradation of azoxystrobin in an aquatic environment is 11 to 17 days. 
Table 2. The motility/movement of miracidia stage of Fasciola hepatica after 16 days of incubation

\begin{tabular}{cccccc}
\hline $\begin{array}{c}\text { Experimental } \\
\text { group }\end{array}$ & Viability & $\begin{array}{c}\text { Experimental } \\
\text { group }\end{array}$ & Viability & $\begin{array}{c}\text { Experimental } \\
\text { group }\end{array}$ & Viability \\
\hline $\mathrm{K}$ & $\mathrm{NE}$ & $\mathrm{GZn}$ & $\mathrm{I}$ & $\mathrm{GCrZn}$ & $\mathrm{I}$ \\
$\mathrm{A}$ & $\mathrm{I}$ & $\mathrm{CdCr}$ & $\mathrm{I}$ & $\mathrm{CdCrZn}$ & $\mathrm{NE}$ \\
$\mathrm{G}$ & $\mathrm{I}$ & $\mathrm{CdZn}$ & $\mathrm{M}$ & $\mathrm{AGCdCr}$ & $\mathrm{I}$ \\
$\mathrm{Cd}$ & $\mathrm{I}$ & $\mathrm{CrZn}$ & $\mathrm{I}$ & $\mathrm{AGCdZn}$ & $\mathrm{I}$ \\
$\mathrm{Cr}$ & $\mathrm{RM}$ & $\mathrm{AGCd}$ & $\mathrm{I}$ & $\mathrm{AGCrZn}$ & $\mathrm{I}$ \\
$\mathrm{Zn}$ & $\mathrm{RM}$ & $\mathrm{AGCr}$ & $\mathrm{NE}$ & $\mathrm{GCdCrZn}$ & $\mathrm{I}$ \\
$\mathrm{AG}$ & $\mathrm{I}$ & $\mathrm{AGZn}$ & $\mathrm{I}$ & $\mathrm{AGCdCrZn}$ & $\mathrm{NE}$ \\
$\mathrm{GCd}$ & $\mathrm{I}$ & $\mathrm{GCdCr}$ & $\mathrm{I}$ & & \\
$\mathrm{GCr}$ & $\mathrm{I}$ & $\mathrm{GCdZn}$ & $\mathrm{NE}$ & & \\
\hline
\end{tabular}

$\mathrm{NE}$ - no effect on movement of emerged miracidia

RM - reduction of the motility of miracidia inside the egg shells

I - immobile/death miracidia inside the egg shells

Studies ranked azoxystrobin among pesticides with moderate persistence in terrestrial environment and general degradation half-life within the range of 72 to 164 days. (US EPA)

Glyphosate is frequently used as a non-selective herbicide to treat many crops (mainly cereals, rape seed, sugar and fodder beet, flax, maize, kernel fruit, strawberries, potatoes, etc.). It is also used to treat pastures, nurseries and non-agricultural land. (Monsanto, 2009) Glyphosate was included in the List of Risk Substances relevant for the Slovak Republic under the Program of Reduction of Water Pollution with harmful and very Harmful Substances for which a program of measures for reduction of water pollution with such substances was designed. Considering the actual agricultural use of glyphosate, there is a need to monitor the substance in the aquatic environment on a regular basis. (Resolution No. 561) Glyphosate ranks among the extremely persistent pesticides with a half-life longer than 100 days (calculated from field studies). Glyphosate was found in streams following agricultural, forestry and urban application. Fish and aquatic invertebrates are more sensitive to glyphosate effects than terrestrial organisms.(Cox, 2000) The EU classified Roundup (Plant protection product containing glyphosate as an active substance) as R51/53 Toxic to aquatic organisms, may cause long-term adverse effects in the aquatic environment (Giesy, 2000).

\section{Conclusion}

Viability of miracidia of Fasciola hepatica was investigated after exposure to cadmium chloride, potassium dichromate, zinc sulfate, glyphosate and azoxystrobin separately or in their combinations. Groups containing zinc ( $\mathrm{Zn})$ and cadmium (Cd) showed better viability of miracidia of Fasciola hepatica. The explanation of that phenomenon may be the well-known effects of zinc that include reduction of harmful effects of cadmium.

\section{Acknowledgements}

The study was supported by grant project VEGA No.
1/0393/08 and the National Reference Laboratory for Pesticides. NRL UVLF-KE.

\section{References}

Cox, C. (2000): Glyphosate factsheet. J. Pestic. Reform, 108(3) Retrieved November 24, 2011 from http://www.mind fully.org/Pesticide/Roundup-Glyphosate-Factsheet-Cox.htm Clough, J. M., Godfrey, C. R. A., Godwin, J. R., JosePh, R. S. I., SPINKS, C. (1996): Azoxystrobin: a novel broadspectrum systemic fungicide. Pestic. Outl., 7(4): 16 - 20 ČERŇANSKÁ, D., VÁRADY, M., ČORBA, J. (2006): A survey on anthelmintic resistance in nematode parasites of sheep in the Slovak Republic. Vet. Parasitol., 135(1): $39-45$. DOI: 10.1016/j.vetpar.2005.09.001

DOLINSKÁ, M., KÖNIGOVÁ, A., VÁRADY, M. (2012): Is the micro-agar larval development test reliable enough to detect ivermectin resistance? Parasitol. Res., 111: 2201 2204. DOI: $10.1007 / \mathrm{s} 00436-012-2944-4$

GIESY, J. P., SOlOMON K. R., DOBSON, S. (2000): Ecotoxicological risk assessment for roundup herbicide. Rev. Environ. Contam. Toxicol., 167: $35-120$

KoČIŠOVÁ, A. (2005): Disinfection - an integral part of prevention of infectious diseases and parasitoses in animal breeding. $D D D, 4: 149$ - 153 (In Slovak)

KorÉNEKOVÁ, B., SKAliCKÁ, M., KorÉNEK, M. (2002): Chromium and animal organism. Infovet, 9(4): 35 (In Slovak) Kobroob, A., ChattiPAKorn, N. AND WongmeKiAT, O. (2012): Caffeic acid phenethyl ester ameliorates cadmiuminduced kidney mitochondrial injury. Chem. biol. interact., 200(1): 21 - 27. DOI: 10.1016/j.cbi.2012.08.026

KotTferová, J., KoréneKovÁ, B., SiklenkA, P., JACKOVÁ, A., HuRNÁ, E., ŠÁLY, J. (2001): The effect of Cd and vitamin $\mathrm{D}_{3}$ on the solidity of eggshell. Eur. Food. Res. Technol., 212: 153 - 155

KRUPICER, I. (1995): Effect of mercury-dominated heavy metal emission on the course of pasture helminthoses in sheep. Vet. Med. - Czech, 40(1): $11-15$

KRUPICER, I., VELEBNÝ, S., LEGÁTH, J. (1996): Effect of emissions from a mercury treating metallurgical works on the intensity of experimental Fasciola hepatica infection in sheep. Vet. Med. - Czech, 41(4): 103 - 106 
LiU X. Y., Jin, T. Y., NordberG, G. F., RAnnar, S., SJosTROM, M., ZHOU, Y. (1992): A multivariate study of protective effects of $\mathrm{zn}$ and $\mathrm{cu}$ against nephrotoxicity induced by cadmium metallothionein in rats. Toxicol. Appl. Pharmacol., 114(2): $239-245$

Monsanto Europe S.A. (2009): Roundup ${ }^{\circledR}$ Biactive, Safety Data sheet. Retrieved November 24, 2011 from https://www.sdslibrary.monsanto.com/MSDS\%20Datashee t/944A0918047638E00625689700650A63/Roundup\%20B iactive-5047en-gb.pdf

Pathak, N., Mitra, S., Khandelwal, S. (2013): Cadmium induces thymocyte apoptosis via caspase-dependent and caspase-independent pathways. J. Biochem. Mol. Toxicol., 27(3): 193 - 203. DOI: 10.1002/jbt.21468

Resolution Of The Government Of The Slovak Republic No. 561 of 16 June 2004 concerning the draft Program for Reduction of Water Pollution with Harmful and Extremely Harmful Substances Annex No. 26 (Glyphosate) Retrieved from http://www.shmu.sk/File/ projekty/tpds/Annex_3_1_ National_Pollution_Reduction_Programme.pdf

Sousa, S. F., Fernandes, P. A., Ramos, M. J. (2007): Theoretical studies on farnesyltransferase: Evidence for thioether product coordination to the active-site zinc sphere. J. Comput. Chem., 28(7): 1160 - 1168

Syngenta group (2005): Azoxystrobin. In: Syngenta Crop Protection - ENVIROfacts. Retrieved November 24, 2011 from http://www.syngentacropprotection.com/env_steward ship/futuretopics/Azoxy2005.pdf

U. S. Environmental Protection Agency (1997): Pesticide fact sheet: Azoxystrobin. Retrieved November 24, 2011 from http://www.epa.gov/opp00001/chem_search/reg_acti ons/registration/fs_PC-128810_07-Feb-97.pdf

VÁRADY, M., ČUDEKOVÁ, P., ČORBA, J. (2007): In vitro detection of benzimidazole resistance in Haemonchus contortus: Egg hatch test versus larval development. Vet. Parasitol., 149(1): 104 - 110. DOI: 10.1016/j.vetpar.2007.07.011 